\title{
POLITICAL ECONOMY OF
}

\section{THE GREEK CRISIS}

\author{
Costas Lapavitsas
}

SOAS University of London

\begin{abstract}
The Greek turmoil commenced as a balance of payments, or "sudden stop", crisis induced by large current account and primary government deficits. It became an economic and social disturbance of historic proportions. Its proximate cause was loss of competitiveness within the Eurozone due primarily to domestic German wage policies. The bail-out policies, imposed by the lenders primarily for reasons of Eurozone stability and adopted by Greece, have had disastrous effects on both economy and society. The "historical bloc" that dominates Greek society willingly submitted to this strategy, losing sovereignty, for reasons including fear and identity.
\end{abstract}




\section{Introduction}

The Greek turmoil began in 2010 in the form of a balance of payments, or "sudden stop", crisis, similar to those of developing countries in the 1980s, 1990s and 2000s, but became a protracted and deeply destructive disturbance of both economy and society. Moreover, since the end of the sharp phase of the crisis in 2013 the country has been unable to resume sustained growth. Analysis of these complex phenomena requires a political economy approach that places economic processes in their appropriate social and political context.

The point of departure for the required analytical approach is that Greece has failed to compete successfully with other member states of the Eurozone, and has assumed a peripheral place within the monetary union. Section 2 of the paper shows that the most prominent cause of weak Greek competitiveness and hence much of the virulence of the crisis - lies with domestic German wage suppression. Loss of competitiveness has compounded the long-term structural problems of the Greek economy which have become worse since entering the EU in 1981. This is the fundamental reason why Greece has confronted a turmoil of exceptional severity and protracted nature in the 2010 s.

The true analytical conundrum, however, is posed by the conduct of the lenders to Greece and even more of the Greek policy makers. Summarily put, the lenders have forced Greece to adopt bail-out policies which have consistently failed to produce expected results. Greek policy makers, on the other hand, have acceded to the policies of the lenders despite the damage inflicted on both economy and society. They have also desisted from proposing, or even advocating, the two policies that could have put the country on a different path, namely debt write off and exit from the Eurozone. As a result, the country has been subjected to unprecedented economic and social dislocation since early 2010, without an obvious end in sight. 
To deal with this conundrum it is necessary to go beyond strictly economic factors. It is argued in section 4 that the stance of Greece reflects a dramatic loss of sovereignty imposed by foreign lenders within the confines of the Eurozone. Acceptance of the loss of sovereignty in turn reflects fear and concerns about identity in case of exiting the monetary union. These elements are most prominent within the Gramscian "historical bloc" that holds power in the country, but have also spread across society. By submitting to the lenders and accepting loss of sovereignty, the Greek "historical bloc" has also weakened the country's long-term growth prospects, as is briefly argued in section 5. The Greek crisis thus casts a harsh light on the nature of the Eurozone and its implications for other peripheral countries of the monetary union.

\section{Facing a balance of payments crisis within the Eurozone}

\subsection{A Greek "sudden stop"}

It is increasingly accepted in the mainstream economic literature that the Eurozone crisis of 2010-12 - and thus also the Greek crisis - was fundamentally a balance of payments crisis, of the "sudden stop" variety, involving a sudden reversal of capital flows from abroad, as has happened frequently in developing countries in the 1980s, 1990s, and 2000s. ${ }^{1}$ This is without denying the deficiencies of the so-called "architecture" of the monetary union, for instance, the absence of a fiscal and banking union to supplement the monetary union. ${ }^{2}$ Deficiencies in the "architecture" of the EMU are unable by themselves to account for the outbreak of a crisis: a specific mechanism is necessary, and that is what the "sudden stop" analysis offers.

Balance of payments crises come in a variety of forms, but tend to break out as private capital flows to private or sovereign borrowers suddenly dry up in 
international markets. Inability to borrow by private or sovereign borrowers sets off a train of events: fall of the exchange rate; shrinkage of domestic credit; inability to make payments to exporters from abroad and to domestic suppliers; and eventually a recession with falling output and rising unemployment.

Since "sudden stop" crises break out in the international financial markets, their immediate causes tend to be associated with the current and the capital account. In the post-Bretton-Woods world of floating exchange rates and free capital flows, a current account deficit can generally be made good through a capital account surplus. Developing countries typically try to peg their exchange rates, often by "shadowing" a major currency, with the aim of stabilising trading conditions. For the peg to be maintained, a current account deficit would have to be balanced reasonably quickly by a surplus on capital account. A threat to the ability to borrow abroad would soon place a deficit country at risk of exchange rate collapse.

From the perspective of international lenders, a growing current account deficit in a developing country is an indicator of increasing reliance on external borrowing. In this connection both domestic fiscal policy and the public debt acquire exceptional importance. For, sustained fiscal deficits absorb domestic loanable capital, encouraging both private and public borrowers to seek funds abroad. If a country has recorded large fiscal deficits and its public debt has risen substantially, international lenders would face an increased risk of default, other things equal. A sustained current account deficit would thus acquire exceptional poignancy for policy makers.

The realisation that the Greek crisis was initially a balance of payments crisis came neither easily, nor naturally, to the policy-making apparatus of the European Union. The official response in early 2010 was that the Eurozone turmoil had been caused by Greek "dishonesty", "incompetence" and the like. Lack of understanding made for not a little vindictiveness toward Greece, and 
even led to the imposition of absurdly punitive interest rates on the initial loans, presumably to deal with "moral hazard". ${ }^{3}$ Only a few voices at the time pointed to the underlying nature of the Eurozone crisis, and these typically came from outside the economics mainstream. ${ }^{4}$

There are no mysteries about the fundamental components of the Greek balance of payments crisis in 2010. The current account exhibited an enormous deficit by 2008, apparent in Figure 1; the fiscal primary balance recorded huge deficits by the late 2000s, shown in Figure 2, although it had appeared to stabilise in the mid-2000s perhaps partly due to "creative" use of statistics by the Greek authorities; and the ratio of public debt to GDP reached very high levels in the late 2000s, as is shown in Figure 3. Indeed, it is remarkable that Greece had avoided the outburst of a crisis in its external transactions in 2009.

<FIGURE 1 HERE>

<FIGURE 2 HERE>

<FIGURE 2 HERE>

There are, however, two issues that have not been adequately addressed in the economic literature on this issue, both mainstream and heterodox. The first concerns the underlying causes of the enormous Greek current account deficit that has catalysed the "sudden stop"; the second refers to the composition of the aggregate Greek debt - private and public, internal and external - which has dictated the path of subsequent events. It is not accidental that both issues are directly related to Greek participation in the Eurozone. For, the Greek balance of payments crisis was ultimately an outcome of the country's membership of the monetary union. 


\subsection{Loss of competitiveness and the Greek crisis}

There are two fundamental approaches to explaining the huge external deficit of Greece in the late 2000s.

The first approach to the deficit stresses the loss of competitiveness by Greece and other countries in the periphery in the preceding years, but contains two very different currents within it. There is a dominant current, which is characteristic of the European Commission, and attributes the loss of competitiveness primarily to domestic causes, namely the frictions, institutional weaknesses, and inefficiencies of Greek economy and society. ${ }^{5}$ By this token a policy of structural reform in Greece, typically of a neoliberal character, would be necessary to restore competitiveness.

There is, however, a further current which attributes the loss of competitiveness by Greece (and much of the periphery of the Eurozone) essentially to German wage policies. It was originally put forth by broadly heterodox economists, and provides the analytical basis for this paper. ${ }^{6}$ The contrast with the dominant current is clear, since the latter downplays, or even completely ignores, the import of German wages and prices for the trajectory of competitiveness within the EMU. ${ }^{7}$

The second approach to the deficit focuses on the flows of bank lending from core to peripheral EMU countries in the 2000s. Presumably these flows encouraged rapid growth of credit in the periphery, thus boosting consumption and real estate speculation, and leading to current account deficits. This approach lays much of the blame for the crisis on banks operating from the core to the periphery, and thus ostensibly opposes the policies of the European Commission. It is shown in section 2.3, however, that this approach is 
unsatisfactory, both theoretically and empirically, particularly for Greece. That is not to deny the problematic role of banks in the Eurozone crisis, which is also broadly appreciated by mainstream economists. ${ }^{8}$

To be more specific, at the root of the Eurozone - and the Greek - crisis lie divergences in competitiveness driven fundamentally by domestic German wage policies, that is by the trajectory of capital-labour relations in Germany. International competitiveness is usually measured by nominal unit labour cost, $\mathrm{C}$, defined as the nominal remuneration of labour, $\mathrm{W}$, divided by real output, $\mathrm{Y} / \mathrm{P}$. If the total number of hours worked, $\mathrm{L}$, was taken into account, $\mathrm{C}$ could be further written as the nominal remuneration of labour per hour worked, W/L, divided by the productivity of labour, Y/PL. Thus:

$$
\mathrm{C}=\mathrm{W} /(\mathrm{Y} / \mathrm{P})=(\mathrm{W} / \mathrm{L}) /(\mathrm{Y} / \mathrm{PL})
$$

It is apparent that, other things equal, a rise in the nominal remuneration of labour would raise $\mathrm{C}$, thus lowering competitiveness, while a rise in the productivity of labour would reduce $\mathrm{C}$, thus raising competitiveness. Finally, it $\mathrm{C}$ tends to be closely correlated with inflation.

On this basis, the decline in Greek national competitiveness in the 2000s is not hard to establish: nominal unit labour costs rose fast, and indeed much faster than Germany, as is shown in Figure 4 for a group of core and peripheral Eurozone countries. 
This was certainly not due to weak growth in Greek labour productivity, which actually rose quite rapidly within the Eurozone, and indeed faster than German labour productivity, as is shown in Figure 5.

\section{<FIGURE 5 HERE>}

There is no doubt that Greek competitiveness within the Eurozone declined essentially because the nominal remuneration of Greek labour rose faster than that of German labour, the latter remaining essentially frozen throughout the 2000s.

The real outlier in the Eurozone in this respect was not Greece but Germany, which has applied extraordinary wage restraint on its own workers since the end of the 1990s. The resulting divergences in unit labour costs (and correlated inflation) could not be offset through the adjustment of exchange rates since the EMU has eliminated that option. Put differently, the EMU has become a trap for its members, since in the 2000s unit labour costs diverged systematically among a group of countries that have historically had dense trade relations, which were typically adjusted through exchange rate realignments. In the absence of adjustment, however, the loss of competitiveness by one has tended to be reflected in the gain of competitiveness by another.

Essentially the same point could also be made in terms of the "real exchange rare" of Greece, which has recorded a substantial real appreciation from the late 1990 s to the late $2000 \mathrm{~s} .{ }^{9}$ The main factors making for appreciation in the 2000s were, first, the higher rate of inflation compared to Germany and, second, the nominal appreciation of the euro compared to the dollar. Considering that the Greek current account deficit was mostly with its trade partners within the EMU, the rise of the euro relative to the dollar was not particularly significant. The paramount factor was, rather, higher Greek inflation relative to Germany. 
This development is correlated to diverging nominal unit labour costs in the two countries.

The secret of German competitive success in the Eurozone has been the essential freezing of nominal wages in the 2000s. Wage freeze was a direct outcome of altered relations among capital and labour (mediated by the state). In the late 1990s the post-war practice of sharing productivity gains via the intervention of the German state was abandoned in favour of capital. The ostensible logic was that labour costs had to be restrained to protect employment. 10 The justification was provided by the approaching monetary union, the difficulty of absorbing the German Democratic Republic, nd the persistence of unemployment. The changes were actually introduced by the Social Democratic government of the late 1990s and early 2000s with the full connivance of the labour unions. Although there was no grand German plan to dominate the EMU, the outcome was an accretion of competitiveness that has transformed Germany into a gigantic exporter within the EU and more generally.

Germany has emerged as the most powerful country in the EU through a peculiar "neo-mercantilism" that has restrained nominal wages, and thus domestic demand, with the aim of boosting exports. The point is of critical importance to the Eurozone crisis, though it remains poorly appreciated in policy making in Europe. It is important in this connection to stress the following:

First, the argument refers to national rather than enterprise competitiveness. National competitiveness relates fundamentally to the operations of the world market, and is ultimately a matter of relative prices in the aggregate. 11 Enterprise competitiveness is a microeconomic concept that also reflects the quality of management, the intensity of labour, and so on.

Second, it is misleading to estimate the proportions of Greek trade with Germany with the aim of demonstrating that the losses of one were (or 
were not) directly the gains of the other. ${ }^{12}$ Greece lost competitiveness relative to Germany and to the rest of the Eurozone; in contrast, Germany gained competitiveness relative to both Greece and the Eurozone. Since both countries trade widely with other Eurozone countries, the divergence in competitiveness has made for a current account deficit for Greece, and a surplus in Germany, both in the aggregate. Furthermore, loss or gain of competitiveness did not translate simply into, respectively, decline or rise of exports: it was also reflected in the fall or increase in imports, respectively.

Third, the argument pivots on changes in and not levels of competitiveness. It is trivially true that Germany is more competitive than Greece. However, there is no need for countries to have similar levels of competitiveness to be able to have balanced trade with each other, or even to be members of the same monetary union. The real issue is the evolution of competitiveness over time.

Fourth, in sharp contrast to the approach of the European Commission, the causes of the divergence of competitiveness did not lie primarily in the domestic economy of Greece, or indeed other peripheral countries. It is no great discovery that Greek capitalism has been marked by a variety of deeply problematic practices, some of which are considered below. The point is that competitiveness is inherently a relative concept and, in the context of the Eurozone, this implies focusing on the domestic policies of Germany, the dominant country.

Fifth, the analytical stress on competitiveness aims at identifying the underlying economic tendencies and has nothing to do with "blaming workers" or similarly fanciful notions. If a country lost competitiveness in the world market, there would inevitably be implications for its economy that must assessed rationally. Moral concern can wait.

To recap, there is no doubt that Geek competitiveness within the Eurozone declined heavily in the 2000s, contributing to a vast current account deficit, which eventually ushered in a balance of payments crisis. The fundamental 
reason for the loss of competitiveness, however, was a German wage freeze during the same period, which also propelled Germany to the dominant position within the Eurozone.

This argument remains fully aware of the structural weakness of the Greek economy as well as of the strong growth in domestic demand and credit that occurred in Greece prior to the crisis. The Greek economy recorded rapid rates of growth in the 2000s, often exceeding $4 \%$, faster than Spain and Portugal. ${ }^{13}$ Investment rose in the late 1990s and continued to rise in the 2000s, though it never reached the levels of Spain and Ireland. ${ }^{14}$ Moreover, Greece has never had a real estate "«bubble»" marked by a rise in residential investment similar to Spain and Ireland. Furthermore, the levels of Greek corporate investment in GDP have remained systematically lower than other peripheral countries throughout the period. ${ }^{15}$ The relative weakness of Greek investment has also been reflected in the strength of consumption, which rose systematically in the 2000s, though always in line with GDP growth. The striking aspect of Greek consumption was not its growth but its high proportion relative to GDP: it stood above $70 \%$, almost $10 \%$ higher than Portugal and even more compared to Spain, Italy and Germany. ${ }^{16}$

Investment and consumption weakness aside, the Greek economy has been marked by a profound shift in its structure since the early 1980s in favour of services and at the expense of the secondary sector. Production of internationally tradable goods has suffered accordingly, and the Greek economy has turned toward non-tradable activities, thus becoming relatively inward looking. ${ }^{17}$ This prominent shift in the structure of the Greek economy was the background against which the loss of competitiveness in the 2000s led to the huge deficit on current account. ${ }^{18}$

Finally, a boost of aggregate demand did take place in the 2000s drawing on credit growth, as is discussed in the next section. Note that credit grew while 
aggregate saving had disappeared; net national saving in Greece has been systematically negative since the country's entry into the Eurozone. ${ }^{19} \mathrm{By}$ implication foreign borrowing has been essential to supporting the country's relatively high rates of growth and investment in the 2000s. Equivalently, when foreign borrowing became impossible after the outbreak of crisis in 2010, both growth and investment collapsed.

\subsection{The aggregate indebtedness of Greece}

Aggregate Greek debt - private and public, internal and external - increased rapidly in the 2000s. The more the country failed to compete within the Eurozone, the more its debt increased, both domestically and abroad. Increasing volumes of aggregate debt, needless to say, are not necessarily a sign of an economy about to enter crisis: it depends on the uses of the accumulated debt. However, in the case of Greece the accumulation of debt was a sign of fundamental weakness and loss of competitiveness.

Aggregate debt in Greece increased from roughly $150 \%$ to a little less than $300 \%$ of GDP in, respectively, 1997 and 2009; nonetheless, in 2009 it was proportionately lower than in Spain and Portugal. ${ }^{20}$ The composition of debt for 2009 showed: public debt at $42 \%$, or $296 \mathrm{bn}$, non-financial corporation debt at $23 \%$, or $165 \mathrm{bn}$, financial corporation debt at $17 \%$, or $120 \mathrm{bn}$, and household debt at $17 \%$, or $123 \mathrm{bn}$. About three quarters of aggregate debt was long-term and the rest short-term. Equally important is that externally owed debt came to $385 \mathrm{bn}$, of which $206 \mathrm{bn}$ was owed abroad by the state and $112 \mathrm{bn}$ by financial corporations.

The trajectory of aggregate Greek debt indicates that there was no credit «bubble» in the 2000s. The fastest growing component of aggregate debt in the 2000s was private debt, in particular debt by financial corporations and 
households, both of which increased markedly. There was certainly strong growth of credit by banks directed toward households and (less) toward nonfinancial enterprises. Greek banks borrowed abroad for liquidity, but relied heavily on domestic deposits and kept well away from derivatives and other forms of financial engineering.

Credit expansion occurred as nominal and real interest rates declined rapidly in the periphery after the adoption of the euro. In that environment Greek banks were able to fund themselves in the interbank markets to support the domestic expansion of credit, though not nearly as heavily as in Spain and Portugal. ${ }^{21}$ This observation alone would suffice to negate the second approach to explaining the Greek external deficit, namely the view that stresses the putative role of foreign bank lending from core to periphery, mentioned in section 2.2, thus assigning the prime explanatory role for the crisis to financial activities. ${ }^{22}$

The stress on finance is theoretically problematic since financial flows are ultimately secondary to the fundamental productive processes in a capitalist economy. ${ }^{23} \mathrm{Be}$ that as it may, emphasising the role of foreign financial capital in the Greek crisis is deeply problematic empirically. For, the expansion of demand in Greece in the 2000s relied on growth of credit that was strongly driven by domestic banks.

It is a fallacy to conflate the domestic expansion of credit with an inflow of loanable capital from abroad which, presumably, led to domestic credit expansion, while at the same time increasing external indebtedness. Nominal interest rates converged dramatically across the EMU as the ECB coordinated the provision of liquidity across the union. However, the divergence in inflation rates (and of nominal unit labour costs) meant that real rates of interest were higher in the core than the periphery, as is shown in Figure 6. It would have been a very strange type of financial capital that actively sought to move from a high to a low interest environment. 


\section{<FIGURE 6 HERE>}

There is no doubt that Greece, similarly to other peripheral countries, borrowed heavily from abroad during the 2000s. The flows were spurred by Greek borrowers, primarily the state and the banks. The macroeconomic functioning of the borrowing basically was to finance the huge deficit on current account, also reflecting the country's negative saving. Foreign banks did not lead the process of credit growth in Greece; rather, the catalyst was burgeoning domestic credit expansion by Greek banks, which took advantage of the relatively homogeneous inter-bank market in the Eurozone in the 2000s to obtain liquidity cheaply. In a country that had for decades deployed high interest rates as an instrument to defend the exchange rate, the low interest rate environment offered unprecedented scope for credit expansion to banks, much of it directed toward households. Historically and culturally household debt has been frowned upon in Greece, but in the late 1990s and the 2000s households borrowed heavily to finance house purchases and consumption. The accumulation of household debt proved a major problem in the 2010s, once the economy had been subjected to bail-out policies.

Public debt rose proportionately less than other parts of aggregate debt in the 2000s, but from an already high base compared to other peripheral countries. Relatively high public debt in Greece has its roots in the 1980s reflecting in part the expansion of welfare provision, and in part the sustained weaknesses of the tax system. To be specific, welfare provision in Greece has always been modest by Western European standards and there has long been systematic tax evasion. The economic and political power of large non-financial corporations and banks has ensured relative tax immunity for the upper echelons of the economy. Significant tax evasion by the upper layers of selfemployed professionals and small and medium enterprises has also been widely tolerated. ${ }^{24}$ Farmers, meanwhile, have historically been given strong tax exemptions ostensibly for reasons of social policy. 
The crisis faced by the Greek state in the 2010s came less from the increase in public debt in the 2000s, as is shown in figure 3, and more from the change in the composition of public debt which, following the country's accession to the Eurozone, became heavily skewed toward foreign lenders. In 2009 the Greek state owed more than 200bn out of a total of nearly $300 \mathrm{bn}$ to foreign lenders, among which French and German banks were prominent; much of the remaining balance was owed to Greek banks. Interest rates had become remarkably low by Greek standards and the country had suddenly acquired a putative creditworthiness as a member of the monetary union. European banks were prepared to lend to the Greek state allowing it to replenish its stock of debt as well as to borrow afresh.

It is notable that these banks failed in the most elementary functions of screening and monitoring of borrowers. ${ }^{25}$ For, a further remarkable aspect of Greek public debt in 2009 was that it was overwhelmingly bond-based, denominated in euro and governed by Greek law. ${ }^{26}$ The lenders had not done their work properly. As the spectre of default arose in 2010 the Greek state held a strong bargaining chip in its hands. Unfortunately, it never used it.

\section{Responding to the crisis: The iron cage of the euro}

There is a tried response to balance of payments crises developed by multilateral organisations and forming a part of the so-called "Washington Consensus". ${ }^{27}$ Still, the Greek crisis offers some fresh insight because it was tried for the first time within a powerful monetary union, such as the EMU.

The first requirement of the response is to deal with the interruption of financial flows from abroad. Typically this translates into restoring the interrupted flows to the private banks, thus preventing a collapse of credit, as well as restoring 
the interrupted flows to the state, thus preventing a formal default. The difficulty is that there are no formal mechanisms in the world market to restore these flows. Thus, the typical practice has been to form ad hoc coalitions of lenders from abroad, including private banks, public institutions and, crucially, the IMF as coordinator and policy specialist. Funding would typically be provided on the basis of "conditionality", namely a series of policy changes and structural reforms to be implemented by the recipient, often designed by the IMF and monitored through the gradual release of funds. Conditionality would normally revolve around the following two issues.

The first is stabilisation of external and internal imbalances, usually to be achieved by reducing domestic demand, i.e., via austerity. Specifically, public deficits would be reduced through higher taxes and/or lower expenditure, and domestic credit would be constrained through interest rate increases. The resulting contraction in aggregate demand would eventually lead to current account rebalancing. The cost in terms of unemployment, disrupted welfare provision, loss of income, and so on, would depend on the extent of the decline of output.

The second is restoring growth, which would typically be achieved by improving competitiveness. Thus, wages and salaries would face downward pressure, partly through rising unemployment, and partly through labour "reforms" that would limit trade union rights, ease dismissals, intensify the precariousness of employment, and so on. Deregulation of markets would also be promoted, including of financial markets often in the hope of encouraging inward flows of foreign capital. Finally, privatisation would be advocated on the grounds that it would result in greater efficiency.

The "stabilisation and growth" approach was applied in its essentials to the Greek crisis. The results of this approach for output, employment, income and the productive structure of crisis-stricken countries have historically been 
negative. In the case of Greece three features deriving from its membership of the Eurozone have made the approach entirely lethal.

The first, and less conspicuous, was the availability of liquidity support for the Greek banking system. In a "sudden stop" crisis the domestic banking system tends to face liquidity pressure that cannot be easily managed by the central bank, particularly if there is a heavy drain on deposits and there are large volumes of bank liabilities denominated in a foreign currency. Additional strain on the banking system could also emerge from bad debts as the economy would begin to contract, thus forcing domestic banks to buttress capital adequacy.

For Greek banks the problem of a liquidity was confronted by the ECB and the Eurosystem providing facilities through the Long-Term Refinancing Operations, Emergency Liquidity Assistance, and the TARGET2 settlement system. The dangerous link between a worsening current account and an ensuing lack of domestic liquidity was thus broken. ${ }^{28}$ At its sharpest in $2010-2$, the Greek crisis never acquired the acute banking aspect that the huge external deficit of the country would have fully justified, other things equal. At the same time, however, liquidity provision became the most decisive lever of power for the lenders on successive Greek governments. By controlling liquidity the lenders allowed the country to remain in the Eurozone, but only on condition of submitting to bail-out conditionality. Additional leverage was afforded to the lenders by providing funds, borrowed by the Greek state, to strengthen the capital adequacy of Greek banks.

The second, and very visible, difference was the absence of an exchange rate that could absorb some of the shock of the "sudden stop" through devaluation. Stabilisation programmes typically, though not always, involve devaluation of the domestic currency which changes the terms of trade and thus rebalances the external deficit in the short term. The impact on domestic inflation would 
depend on the "pass through" from import prices to domestic production. Devaluation cannot be a long-term solution to competitiveness problems as its impact would eventually pass onto domestic prices, but in the short term it could lessen the pressure on the domestic economy, especially if measures were also taken to support workers and enterprises. ${ }^{29}$ Even in the long run, moreover, devaluation could create fresh fields for investment and production by sharply changing relative prices. None of these options were available to Greece within the Eurozone.

The third difference was the difficulty of lowering the burden of public debt through restructuring. Typical methods of reducing the cost of servicing the debt include lowering interest rates, and extending the maturity of debt. These measures would increase the fiscal space available to the government, thus ameliorating austerity. A more decisive method of reducing the burden of debt would be to write off some of the principal of the loans, thus also reducing the pressure of refinancing the debt. ${ }^{30}$

Restructuring inevitably entails losses for the lenders - typically private bondholders and banks - thus raising the issue of recompense. Since there are no formal international bankruptcy procedures to deal with public debt, its restructuring would rely on the balance of sovereign power in the world economy. A sovereign state could always default, assuming that the country would be prepared to shoulder the cost of legal proceedings and its exclusion from the financial markets for a period. Equally, the sovereign states of the lenders would seek either to prevent default and restructuring, or at least to limit its incidence on their lending institutions and individuals.

In the case of Greece there is undeniable evidence that the IMF was fully aware of the importance of devaluation and debt restructuring already in 2010. ${ }^{31}$ However, EMU membership made formal devaluation impossible and debt relief was bluntly rejected by Eurozone lenders. Thus, the IMF laid great stress 
on "internal devaluation" pivoting essentially on wage reductions. There is no evidence that the beneficial impact of devaluation and debt relief could be replicated internally, within a reasonable range of values for economic magnitudes. By its own admission, the IMF ignored its own research and simply kowtowed to political pressure from the lenders to Greece, who were among its major shareholders. ${ }^{32}$ In 2010, a Greek default, or even major debt restructuring, and Greek exit from the EMU would have posed grave risks for the banks of the lenders but also for the very survival of the monetary union. From the perspective of the lenders, Greece had to be kept in the EMU. It also had to bear the brunt of the adjustment without debt restructuring or devaluation. The EMU had placed the country in an iron cage and the results would soon show.

In 2010 Greece received its first bail-out, the EU and the IMF jointly providing funds to replace the interrupted private capital flows and thus allowing the Greek state to continue to meet its payment obligations. Needless to say, the main obligation of the Greek state was to keep servicing its existing debt, thus avoiding default. ${ }^{33}$ It was understood that the ECB would continue to provide liquidity to keep the Greek banks afloat. The programme was "frontloaded", meaning that the fiscal adjustment would involve cuts in public expenditure for the initial period, followed by increases in taxes. A full set of conditionality conditions were also specified, along the general lines indicated above. If Greece wished to remain in the Eurozone, there would be no devaluation and no debt restructuring.

The Greek bail-out agreement of 2010 is arguably one of the worst documents on economic policy ever drafted. The bail-out agreement bore no relation to the realities of the Greek economy, and nor to the likely impact of the proposed policies. For, the magnitude of the putative fiscal adjustment was enormous, the external deficit huge, and the competitiveness gap gigantic - and the adjustment had to occur within the iron cage of the EMU. IMF economists have officially admitted that their estimates of the multipliers of the Greek economy 
were low, and thus their assessment of contractionary effect of austerity was very optimistic. ${ }^{34}$ Disaster duly followed.

Aggregate demand contracted violently, and output fell by nearly $7 \%$ in both 2011 and 2012, the total contraction exceeding 25\% in 2008-2016. The most profound fall has been in investment as enterprises reacted to the decline in demand, but also as credit conditions became tighter with banks facing large volumes of problematic public debt on their balance sheets. Equally bad for enterprises, but much less noticed, has been the effective disappearance of commercial credit among enterprises. The collapse in output dramatically increased adult unemployment, which exceeded 27\% in 2013.

It was apparent already by the middle of 2011 that the first bail-out programme had backfired badly. Above all, the recession had worsened the ratio of public debt to GDP, shown in figure 3, and Greece continued to face severe difficulties in servicing its debt. The country needed a new bail-out and urgent debt restructuring. By that time, furthermore, the balance of political forces in Europe had been significantly altered since early 2010. For one thing, European banks had begun substantially to disengage themselves from Greece already in 2010. For another, the EU had begun to establish a panoply of institutions to confront sovereign debt problems, including the European Financial Stability Fund, which eventually became the European Stability Mechanism, the European Financial Stabilization Mechanism, the Securities Market Programme, and Outright Monetary Transactions by the ECB. The risks arising from a Greek default and exit had been attenuated.

In 2012 Greece received a second bail-out with attached conditionality. During 2011-12, furthermore, the country received some debt restructuring which was remarkable for its one-sided and limited nature. Debt relief offered to Greece included extended periods of grace on the bail-out loans, a reduction in average interest rates by granting the fresh funds at concessional rates, and a 
lengthening of the average maturity of debt. ${ }^{35}$ There was also debt restructuring - the so-called Private Sector Involvement - which effectively wrote off some of the principal of Greek debt. In 2012 Greece implemented a bond swap and subsequently a debt buy-back that resulted in nominal debt relief of more than 100bn. ${ }^{36}$

Unfortunately for Greece, the bulk of the losses fell on domestic rather than foreign lenders, the latter escaping with minimal damage. Greek banks in particular were badly affected, and the country was forced to use a large part of the bail-out funds for bank recapitalisation. There cannot have been many other historical instances of sovereign default which have hurt domestic far more than foreign lenders. Moreover, the bail-out funds eventually changed the composition of Greek public debt which by 2012 had become mainly bilateral or multilateral state debt, governed by international law. ${ }^{37}$ Greece had lost its main bargaining chip without ever using it.

Finally, in 2015 Greece has needed a third bail-out, following significant political upheavals and the imposition of capital controls, which are considered in the following section. The underlying cause of the third bail-out was much the same: the economy had contracted enormously and public debt was impossible to service. The conditionality attached to the third bail-out was of similar nature, but by 2015 much of the fiscal and the external adjustment of the country had already been accomplished. The pressing problem for Greece had become the achievement of sustainable growth and development rather than stabilisation. Before considering this issue, however, it is necessary to examine more closely the social and political forces that have kept Greece within the Eurozone at such tremendous cost to its economy and society.

\section{The social and political setting of the Greek crisis}


The outlook of its lenders toward Greece - represented by the "troika" of the EU, the IMF and the ECB - presents few analytical difficulties. The Washington Consensus has held powerful ideological sway among the international organisations. To make matters worse, European policy makers initially perceived the crisis as the result of Greek fiscal mismanagement and "dressing up" the official statistics. Only gradually did the realisation emerge that a fullblown Eurozone crisis was actually unfolding, which required a more coherent approach.

The dominant role in devising the new policy approach of the Eurozone was played by Germany, a country in which there is an entrenched ideological belief that "success" in the 2000s has been due to painful "reforms" in the late 1990s. There has been no powerful domestic constituency in Germany pushing for a programme to rebalance the entire Eurozone by shifting Germany away from its neo-mercantilism. The political message emanating from the country's establishment was - and remains - that Germany is the model for the EMU, and therefore austerity is the appropriate policy for the periphery and elsewhere. ${ }^{38}$

In the realm of material interests, on the other hand, the first priority of the "troika" has been to protect the lenders from losses and the Eurozone from the threat of a major rupture, as the IMF has openly admitted. ${ }^{39}$ If Greece had been offered an alternative programme in 2010, there could have been major material damage to the Eurozone and its core states. Thus, Greece had to be prevented from defaulting and exiting the EMU, while submitting to a programme along the lines of the Washington Consensus.

As the crisis unfolded, the attitude of the EU toward Greece has changed considerably, not least because of the raft of institutions that have been created - above all the European Stability Mechanism - which appear capable of dealing with balance of payments crises in the future. At the same time the EU 
has instituted a permanent regime of fiscal discipline including penalties for "delinquent" countries through the Fiscal Compact of 2012. In essence, the Stability and Growth Pact that had formally supported the introduction of the euro has been re-strengthened in the direction of institutionalised austerity under EU surveillance. Steps have also been taken to create a Banking Union, above all, by giving the ECB the right to monitor banks and their capital adequacy. The Greek crisis has acted as a catalyst for these developments, which have strengthened the position of the lenders relative to Greece. Already by 2012 the EU could contemplate with considerable equanimity the prospect of a Greek default and exit from the EMU.

The position of the IMF toward Greece has also changed significantly in the course of the crisis. The Greek programme has rightly been perceived as a failure, which has moreover led to substantial exposure by the Fund to Greece. The IMF has also clashed with the EU on the question of conditionality which the EU bureaucrats have intended to make highly intrusive, attempting to reshape Greek society and the Greek state; the IMF, in contrast, has aimed primarily at achieving macroeconomic targets. The EU has largely prevailed and a welter of "reform" measures have been directed toward the periphery, often creating confusion for national authorities. ${ }^{40}$

The shifting attitude of the IMF has become apparent in the third Greek bail-out in 2015, in which the Fund has not participated officially as a lender. The sticking point has been the sustainability of Greek debt in conjunction with the policy of austerity. The IMF has advocated writing off some of the principal of Greek debt, with a concomitant relaxation of fiscal austerity in the medium term. The EU would not easily concur since losses on Greek debt would be borne directly by public institutions in Europe, thus creating political and electoral repercussions. 
If the attitude of the lenders in the Greek crisis is relatively complex, the attitude of the borrower presents a real conundrum. Why did Greece in 2010 accept a programme that was manifestly defective, and why has it persevered with bailouts for several years in spite of the damage wrought to economy and society? To find an answer it is important to stretch the analysis by focusing on the outlook of the Greek "historical bloc", to use the well-known term by Gramsci referring to an alliance of dominant sections of the capitalist class with lower classes, which plays a hegemonic role in the economy, politics and culture of a country. ${ }^{41}$

This is not the place to offer a sociological description of the Greek "historical bloc" in the decades following the country's accession to the EU in 1981. Suffice it to state that the dominant bourgeois elements of the bloc have included shipowning, banking, construction and manufacturing, which have also had widespread ownership and control over the mass media. These elements have had considerable influence over the state machine translating into privileged access to public procurement and institutionalised tax avoidance. The Greek state in the post-war decades has followed its own long historical tradition of deploying the forms of a democratic polity, while in practice treating society as an occupied foreign territory for the purposes of tax and welfare provision. ${ }^{42}$ The resulting mechanisms of integration and social control have had a strong admixture of party politics, a characteristic feature of the Greek social formation. The "historical bloc" that has thus emerged has also included layers of the professional self-employed, elements of small and medium businesses, and the larger agrarian landholders, all of whom have secured variable tax and other privileges through a complex electoral machinery connected to the state.

The point to grasp about the Greek "historical bloc" in the face of the crisis of 2010 was not what it decided to do but rather what it has been absolutely determined not to do. And that is to exit the EMU. There can be no doubt on this score as it has been restated countless times by government officials and others, not to mention being confirmed by the practice of several Greek 
governments. For the Greek "historical bloc" staying in the EMU became an article of faith.

Successive Greek governments have thus accepted confronting the crisis without possessing command over monetary and exchange rate policy. By the same token, fiscal policy would be rigidly determined by the "troika", credit policy would be increasingly set by the Banking Union, and trade policy would be shaped by a series of EU directives. The vicious nature of the Greek crisis has resulted largely from the dramatic loss of sovereignty and the lack of command over the economic policy instruments. The only option available to Greek governments since 2010 has been to attempt to change particular details of the bail-out programmes, while complaining about the attitude of the "troika". The exception was the first SYRIZA government, elected in January 2015 on a platform of radical policy change. When that government capitulated and signed the third bail-out in August 2015, Greece returned to its previous stance.

Why, then, has the Greek "historical" bloc acceded to a programme that has profoundly damaged the country? What explains the extraordinary - and extraordinarily destructive - determination to remain in the iron cage of the euro almost regardless of economic and political cost?

Part of the explanation relates to sectional economic interests within the bloc, notably the Greek banks. Without sustained ECB liquidity provision and without access to bail-out funds for recapitalisation, Greek banks would have been forced to suspend operations as well as facing possible nationalisation. Quite naturally banks have been the strongest and most unwavering supporters of bail-out programmes in Greece. However, the acquiescence of the Greek industrial and manufacturing capital, particularly of the construction sector, is harder to explain. As investment collapsed, the productive sector of Greece has faced a level of destruction that is of historic dimensions. Accounting for the acquiescence of productive capitalists to bail-out policies requires broader 
arguments regarding the power structures of Greek society as well as the political outlook and culture of the Greek people.

One factor has been plain fear. For, default and exit would have led to economic and social turmoil in the short-term that would have been likely to generate political unrest. In such circumstances there could be no guarantees of which political forces would emerge to challenge for power. The risk for the Greek "historical bloc" was simply too great. From this perspective it was a rational decision to accept the path of the bail-outs and the attendant loss of sovereignty rather than risk profound social and political unrest. Moreover, in 2010 it was not easy for many to discern the trajectory of destruction that the bail-outs would entail. Once the grim reality had begun to emerge in 2011-12, it was still easier for the "historical bloc" to continue with the bail-outs in the forlorn hope that each step would be the last. Fear of default and exit became an entrenched part of Greek public debate, cultivated assiduously by mass media outlets typically owned powerful business interests, through outlandish claims of the destruction that was likely to follow, including food shortages, lack of medicines, and violent unrest in the streets with looting and arson.

The fears of the Greek "historical bloc" were indeed justified. Mass reaction to the bail-out measures did occur in 2011-12, subsequently taking overtly political forms as the electorate turned to SYRIZA, until then a tiny and untried party of the Left. SYRIZA had only very limited connections to the established mechanisms of power in Greek politics and the state, and spoke the language of wholesale reform and even rebellion in Greece and Europe. The leadership of SYRIZA never explicitly promised unilateral default and exit from the Eurozone, although it hinted that it would consider both options. Its strategy was that it could achieve the lifting of austerity and substantial debt restructuring through "tough negotiations" with the European lenders, who would presumably relent in the face of the democratic legitimacy of a new SYRIZA government. At the same time, the party contained a vocal minority that advocated unilateral 
default and exit from the EMU. The threat to the Greek "historical bloc" was real and present.

SYRIZA won power in January 2015 and the strategy of its leadership was tested in protracted negotiations with the lenders. It became rapidly apparent that the strategy was completely unrealistic. Debacle followed as the ECB limited the provision of liquidity to Greek banks thus causing a gradual disruption of economic activity, and eventually forcing the government to impose banking and capital controls in July 2015. The SYRIZA leadership had not prepared for, and lacked the will to take, the path of default and exit. It surrendered in August 2015, signing up the third bail-out and Greek politics returned to "normality".

In explaining the attitude of Greece, however, even more important than fear has been the notion of identity attached to the euro. Money is an integral part of national and social identity. ${ }^{43}$ The euro in Greece has come to symbolise a "European" identity that overcomes national divisions and is associated with modernity, forward thrust and capturing the future. In a small peripheral country that has historically identified "progress" with developments in Western Europe, these were very powerful ideological factors. Abandoning the euro and reintroducing a national currency would appear as stepping backwards and weakening the "European" identity of the Greek people. ${ }^{44}$ These arguments, relentlessly cultivated by the intellectual elite, acquired extraordinary purchase leading to an astonishing uniformity of thought in the public domain. ${ }^{45}$

Fear and identity backed by powerful material interests have proven a potent mix that has succeeded in keeping Greece within the framework of bail-out policies, and thus in the EMU. The Greek "historical bloc" has preferred to accept a substantial loss of sovereignty and the destruction of much domestic economic activity, rather than adopt the path of default and exit. This momentous choice, quite apart from the damage it has entailed for the country 
hitherto, has also raised the spectre of long-term economic and social decline, as is briefly discussed in the following section.

\section{Whither Greece?}

By 2016, six years after adopting bail-out policies, Greece had achieved a degree of stabilisation. The competitiveness gap was partly closed chiefly through the collapse of Greek nominal (and real) wages in 2010-2013, as is shown in figure 4. However, as is also clear from figure 4, the gap with Germany has effectively stopped narrowing since 2014 . The competitive weakness of Greece in the Eurozone has not been fundamentally eliminated.

The problem that this poses for the country is immediately apparent: competitiveness could be further raised through either more wage reductions, or through a rapid and sustained rise in productivity. The former runs the risk of generating intolerable social and political pressures, given the state of economy and society. As for the latter, there is no evidence at all that it could occur within the framework of the Washington Consensus stressing deregulation and privatisation. In short, without devaluation, Greece is likely to remain in a competitiveness mire.

The continuing weakness of the Greek economy is also apparent for several more specific reasons:

i)The deficit on current account has been effectively eliminated, as is shown in figure 1, but mostly through a collapse of imports due to the contraction of the economy. Greek exports have shown little or no dynamism over time.

ii)The fiscal primary deficit has also been largely eliminated, as is shown in figure 2, through deep reductions in expenditure and substantial increases in taxation. However, tax income has consistently failed to 
meet targets and a huge backlog of unpaid obligations by the public to the state has emerged. This is matched by the backlog of delayed payments by the state to the public.

iii)Public debt stands in the vicinity of $180 \%$ of GDP, as is shown in figure 3 , and is unsustainable.

iv)Investment has collapsed, standing at barely above $10 \%$ of GDP, and matching the negative net saving of the country.

v) Unemployment rose to above $27 \%$ in 2014 and in the following two years has declined gently to just over $23 \%$, partly as a result of rapid growth in part-time precarious employment, and partly due to large scale emigration by trained youth. Greece faces substantial long-term unemployment.

v)The Greek banking system has become heavily concentrated in the course of the bail-outs, and four "systemic" bank have come to control the bulk of deposits and loans. Banks have suffered a sustained loss of deposits, on which they have historically relied for liquidity. Banks also face a tremendous accumulation of non-performing exposure, and although they appear to be well capitalised a large proportion of their capital comprises deferred tax liabilities. The imposition of capital controls in 2015 has prevented a banking collapse, but at the same time it has meant that deposits are unlikely to return en masse to Greek banks in the foreseeable future. Moreover, in November 2015 the four "systemic" Greek banks engaged in large scale equity issue to buttress their capital adequacy in line with EU directives on the Banking Union. As a result public ownership of banks has been dramatically reduced, the public sums previously given to banks for recapitalisation have effectively evaporated, and international hedge funds have acquired significant equity stakes in Greek banks. Under these conditions it is highly unlikely that there would be a strong revival of bank credit in the foreseeable future. 
In the late 2010s Greece has found itself in a position similar to that of Germany immediately after the First World War. As Keynes famously argued, the victors' peace at Versailles had forced Germany to pay huge reparations, while simultaneously precluding it from securing the external surplus that would allow it to make the payments. ${ }^{46}$ In the 2010s Greece - and much of the Eurozone periphery - is weighed down by enormous debt and is saddled with policies that are unlikely to support growth. German neo-mercantilism has made it unlikely that Greece would be able to generate the external surpluses necessary to service its debt.

The social implications of the bail-outs, meanwhile, have been exceptionally severe. Greece has suffered from a rapid increase of poverty; there has been a decline in primary health care; primary and secondary education have faced cuts in resources; homelessness and shared housing have escalated. The contraction of output has also led to a collapse of real estate prices, while at the same time taxation on real estate has increased substantially. The result has to been a trap for real estate owners: able to sell only at substantial loss, they face significant increases in real estate taxes and declining income.

Even worse, there is no reason to assume that the administrative capabilities of the Greek state have substantially improved as a result of the bail-outs. Indeed they might have even declined in some areas as there has been loss of employment, real wages have declined, and morale is low in the public sector. To make matters worse, the power of the lenders is manifested through the presence of the "troika" in several key locations within the state. Not a single economic or social decision can be made by the Greek state without the agreement of the "troika" that it complies with fiscal targets.

In sum, the future of Greece in the Eurozone looks bleak. The country will probably face low and unstable growth in the coming years, with large unemployment, persistent poverty and social dislocation. The political 
counterpart to economic weakness will be a state incapable of exercising sovereignty over key areas of policy, and subservient to the demands of the lenders.

To avoid this path Greece should consider precisely the policy options that its "historical block" has consistently evaded, i.e., default and exit from the Eurozone. Needless to say, the country would also need a plan for national revival focusing on saving, investment and targeted industrial policies. The immediate prerequisite for such a change on strategy would be a restoration of sovereignty. It remains to be seen whether the Greek people have the strength to create a new "historical bloc" that could revamp the prospects of their country. 


\section{REFERENCES}

Aliber, R. Z. (2010) The devaluation of the Greek euro, International Political Econ-omy, Special Report, pp. 1-3, February 17, 2010.

Artavanis, N., A. Morse, and M. Tsoutsoura, 2012, Tax Evasion Across Industries: Soft Credit Evidence from Greece, NBER Working Paper No. 21552, issued in September 2015, available in earlier form at https://www.chicagobooth.edu/blogs/informingreform/docs/taxevasion.p df

Baldwin, R. and F. Giavazzi, (eds.), 2015, The Eurozone Crisis: A Consensus View of the Causes and a Few Possible Solutions, VoxEU.org Book, London: CEPR Press.

Bibow, J, 2012, The euro debt crisis and Germany's euro trilemma, Working Paper No. 721, Levy Economics Institute of Bard College.

Blanchard, O. and D.Leigh, 2013, Growth Forecast Errors and Fiscal Multipliers, IMF Working Paper, WP//13/1, available at https://www.imf.org/external/pubs/ft/wp/2013/wp1301.pdf

Bofinger, P. 2015. "German wage moderation and the Eurozone crisis", Social Europe. 1 December. At: http://www.socialeurope.eu/2015/12/germanwage-moderation-and-the-eurozone-crisis/

Buchheit, L. and M.Gulati, 2010, How to Restructure Greek Debt, Duke Law

School Working Paper, available at

http://papers.ssrn.com/sol3/papers.cfm?abstract id=1603304.

Buti, M. and N. Carnot, 2012, The EMU Debt Crisis: Early Lessons and Reforms, Journal of Common Market Studies, 50: 899-911.

Calvo, G., 2007, "Crises in Emerging Market Economies: A Global Perspective," NBER Working Paper No. 11305, April. Published by the Central Bank of Chile.

Calvo, G., A. Izquierdo, and E. Talvi, 2006, "Phoenix miracles in emerging markets: recovering without credit from systemic financial crises", Technical report, National Bureau of Economic Research.

De Grauwe, P. 2011, "A less punishing, more forgiving approach to the debt crisis in the Eurozone", Centre for European Policy Studies Brief, no. 230, January, available at

https://www.ceps.eu/system/files/book/2011/01/Policy\%20Brief\%20No \%20230\%20De\%20Grauwe\%20on\%20Debt\%20Punishment.pdf

Felipe, J. and U. Kumar, 2011, Unit labor costs in the Eurozone: The competitiveness debate again, Working Paper No. 651. Levy Economics Institute of Bard College. 
Fine B., C. Lapavitsas and J. Pincus, 2001, (eds), Development Policy in the Twenty-first Century: Beyond the Post-Washington Consensus, Routledge: London.

Flassbeck, H. and C. Lapavitsas, 2013,"The Systemic Crisis of the Euro: True Causes and Effective Therapies", Rosa Luxemburg Stiftung Studien, available at

http://www.rosalux.de/fileadmin/rls uploads/pdfs/Studien/Studien The systemic crisis web.pdf

Flassbeck, H. and C. Lapavitsas, 2015, Against the Troika: Crisis and Austerity in the Eurozone, Verso: London and New York.

Gabrisch, H. and K. Staehr, 2014. The Euro Plus Pact: cost competitiveness and external capital flows in the EU countries, Working Paper Series No. 1650, Frankfurt: European Central Bank.

Giurlando, P. 2016, Eurozone Politics: Perception and Reality in Italy, the UK, and Germany, Routledge: London and New York.

Gourinchas P.O., T. Philippon, and D. Vayanos, 2016, The Analytics of the Greek Crisis, in M. Eichenbaum and J. Parker (eds), NBER Macroeconomics Annual 2016, Volume 3, available at http://www.nber.org/chapters/c13780.pdf

Greek Public Debt Management Agency, Public Debt Strategy, available at http://www.pdma.gr/index.php/en/

Hoepner, M. 2014, Europe would be better off without the Euro, Labour History, 55: 5, pp. 661-666.

International Monetary Fund, Independent Evaluation Office, 2016, The IMF and the Crises in Greece, Ireland and Portugal: An Evaluation by the Independent Evaluation Office, July, available at http://www.ieoimf.org/ieo/files/completedevaluations/EAC REPORT\%20v5.PDF

Katsimi, M. and T. Moutos, 2010, EMU and the Greek crisis: The politicaleconomy perspective, European Journal of Political Economy, 26, pp. 568-576.

Katsinos, A. and T. Mariolis, 2012, Switch to devalued drachma and cost-push inflation: A simple input-output approach to the Greek case, Modern Economy, 3, pp. 164-170.

Keynes, J.M., 1929, "The German transfer problem," Economic Journal, Vol. 39, No. 153, pp. 1-7.

Kostis, C. (2015), The Spoiled Children of History, in Greek, Patakis: Athens.

Lane, P.R, 2012, The European sovereign debt crisis, Journal of Economic Perspectives, 26 (3): 49-68.

Lapavitsas, C. 2013, Profiting without Producing: How Finance Exploits Us All, Verso: London and New York. 
Lapavitsas, C., A. Kaltenbrunner, D. Lindo, J. Michell, J.P. Painceira, E. Pires, J. Powell, A. Stenfors, N. Teles, 2010a, "Eurozone Crisis: Beggar Thyself and Thy Neighbour", RMF occasional report, March, available at http://www.erensep.org/images/pdf/rmf/eurozone reports/Eurozone-

$\underline{\text { Report-1.pdf }}$

Lapavitsas, C., A. Kaltenbrunner, G. Lambrinidis, D. Lindo, J. Meadway, J. Michell, J.P. Painceira, E. Pires, J. Powell, A. Stenfors, N. Teles, 2010b, "The Eurozone between Austerity and Default", RMF occasional report, September, available at

http://www.erensep.org/images/pdf/rmf/eurozone reports/Eurozone-

Report-2.pdf

Lapavitsas, C., A. Kaltenbrunner, G. Lambrinidis, D. Lindo, J. Meadway, J. Michell, J.P. Painceira, J. Powell, E. Pires, A. Stenfors, N. Teles, and L.

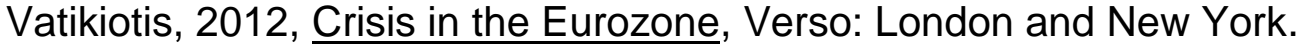

Lapavitsas, C. and D. Munevar, 2014, Greece Needs a Deep Debt Write-Off, RMF Occasional Policy Paper, 10, available at http://www.erensep.org/images/pdf/rmf/occasional policy papers/RMF -OPP-10-Lapavitsas-Munevar.pdf

Mariolis, T., 2016, The foreign-trade leakages in the Greek economy, Paper presented at the workshop: 'What is the future for Europe?' of the European Research Network on Social and Economic Policy, AUTh., 2627 April 2016.

Merler, S. and J. Pisani-Ferry, 2012, "Sudden Stops in the Euro Area," Policy Contribution, March, Brussels: Bruegel. Available at http://bruegel.org/2012/03/sudden-stops-in-theeuro-area-2/

Michalis Nikiforos, N., D. Papadimitriou, and G.Zezza, 2016, "The Greek Public Debt Problem", Working Paper No. 867, Levy Economics Institute of Bard College, May. Availabe at:

http://www.levyinstitute.org/pubs/wp 867.pdf

Obstfeld, M., 2013, Finance at Center Stage: Some Lessons of the Euro Crisis, Economic Papers 493, European Commission on Economic and Financial Affairs, April. Available at:

\section{http://ec.europa.eu/economy finance/publications/economic paper/20} 13/pdf/ecp493 en.pdf

Scharpf, F. 2010, Community and Autonomy: Institutions, Policies and Legitimacy in Multilevel Europe, Publication Series of the Max Planck Institute for the Study of Societies, Cologne, Germany, vol. 68, Campus Verlag: Frankfurt/New York, available at:

http://www.mpifg.de/pu/mpifg book/mpifg bd 68.pdf

Scharpf, F. 2016, Forced Structural Convergence in the Eurozone - Or a Differentiated European Monetary Community, MPIfG Discussion Paper 16/15, available at: 


\section{http://www.mpifg.de/pu/mpifg dp/dp16-15.pdf}

Storm, S, and C.W.M. Naastepad, 2015, NAIRU economics and the Eurozone crisis. International Review of Applied Economics 29 (6): 843-877.

Streeck, W. How Will Capitalism End?, Verso: London and New York.

Pisani-Ferry, J., 2011, The Euro Crisis and Its Aftermath, Oxford; Oxford University Press.

Pisani-Ferry, J., A. Sapir, and G. Wolff, 2013, EU-IMF Assistance to Euro-Area Countries: An Early Assessment, Blueprint 19, Brussels: Bruegel.

Ricardo, D., 1817, [1951], The Principles of Political Economy and Taxation, in The Works and Correspondence of David Ricardo, edited by Piero Sraffa and Maurice Dobb, Cambridge: Cambridge University Press.

Rocholl, J., and A. Stahmer. 2016. "Where did the Greek bailout money go?" ESMT White Paper No. WP-16-02. Berlin: European School of Management and Technology. Available at:

\section{http://static.esmt.org/publications/whitepapers/WP-16-02.pdf}

Sinn, H.W., 2014. Austerity, growth and inflation: remarks on the Eurozone's unresolved competitiveness problem, The World Economy, 37 (1): 1-13.

Skaperdas, S., 2011, Seven Myths about the Greek Debt Crisis, UC Irvine Working Paper, October, available at http://www.socsci.uci.edu/ sskaperd/SkaperdasMythsWP1011.pdf

Sotiris P., 2013, Gramsci and contemporary Left strategy: The "historical bloc" as a strategic concept, Paper submitted at the $10^{\text {th }}$ annual conference of Historical Materialism, available at http://www.historicalmaterialism.org/conferences/annual10/submit/gra msci-and-contemporary-left-strategy-the-historical-bloc-as-a-strategicconcept/

Vavouras, I., 2013, Economic Policy, (in Greek), Papazisis: Athens.

Wren-Lewis, S. 2015. "Was German undercutting deliberate?", Social Europe. December 4. At: http://www.socialeurope.eu/2015/12/was-germanwage-undercutting-deliberate/

Wyplosz, C. 2013. Eurozone crisis: it's about demand, not competitiveness, The Graduate Institute, Geneva, and CEPR. Available at:

https://www.tcd.ie/Economics/assets/pdf/Not competitiveness.pdf

Wyplosz, C. and S. Sgherri, 2016, The IMF's Role in Greece in the Context of the 2010 Stand-By Arrangement, Independent Evaluation Office Background Paper, BP/16-02/11, available at http://www.ieoimf.org/ieo/files/completedevaluations/EAC BP 160211 The IMFs Role in Greece in the Context of the 2010 SB A.PDF

Zettelmeyer, J. C. Trebesch, and M. Gulati, 2013, "The Greek Debt Restructuring: An Autopsy," Economic Policy, 28(75), pp. 513-563. 


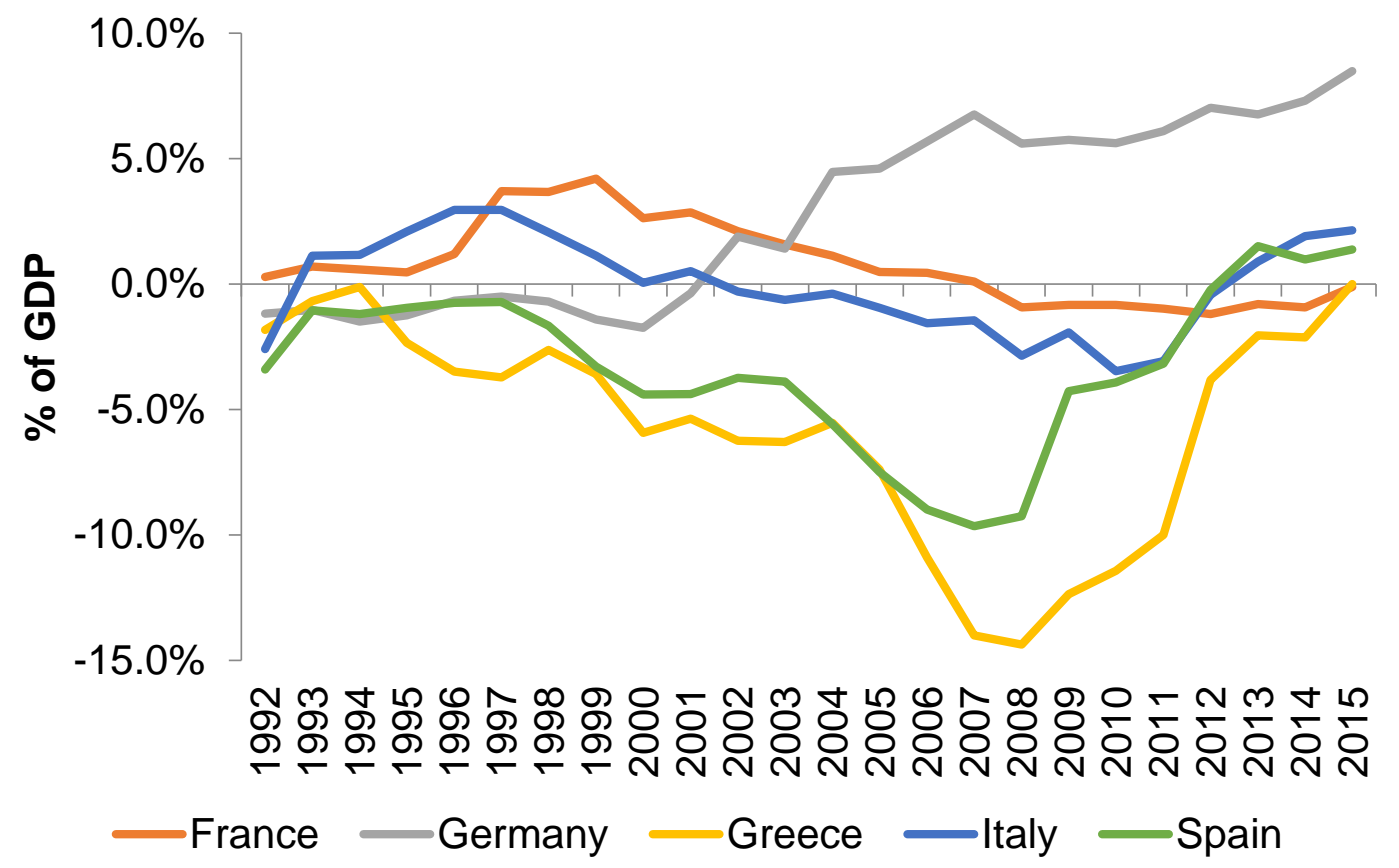

Source: Constructed from AMECO data.

Figure 2

Primary Balance as \% of GDP

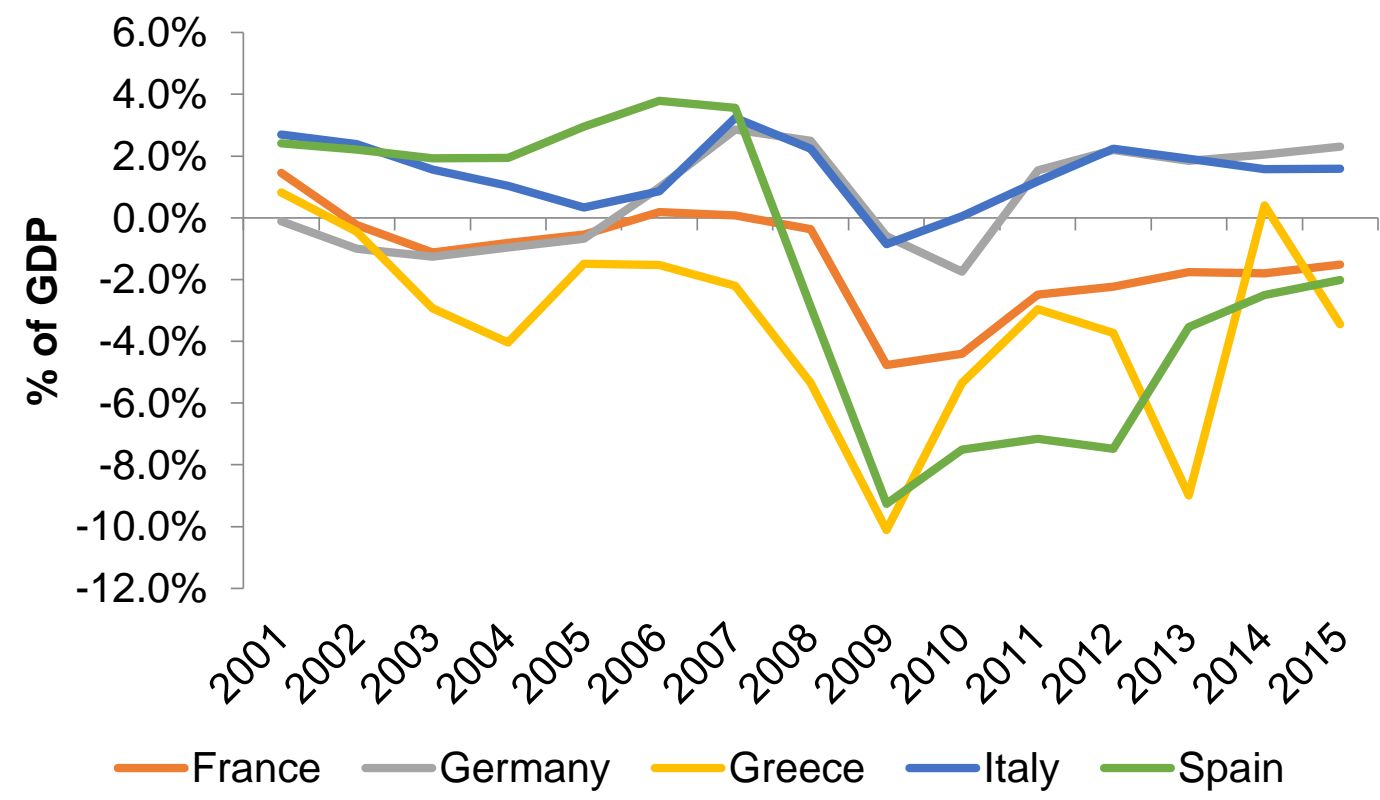

Source: Constructed from AMECO data. 
Figure 3

Gross Public Debt as \% of GDP

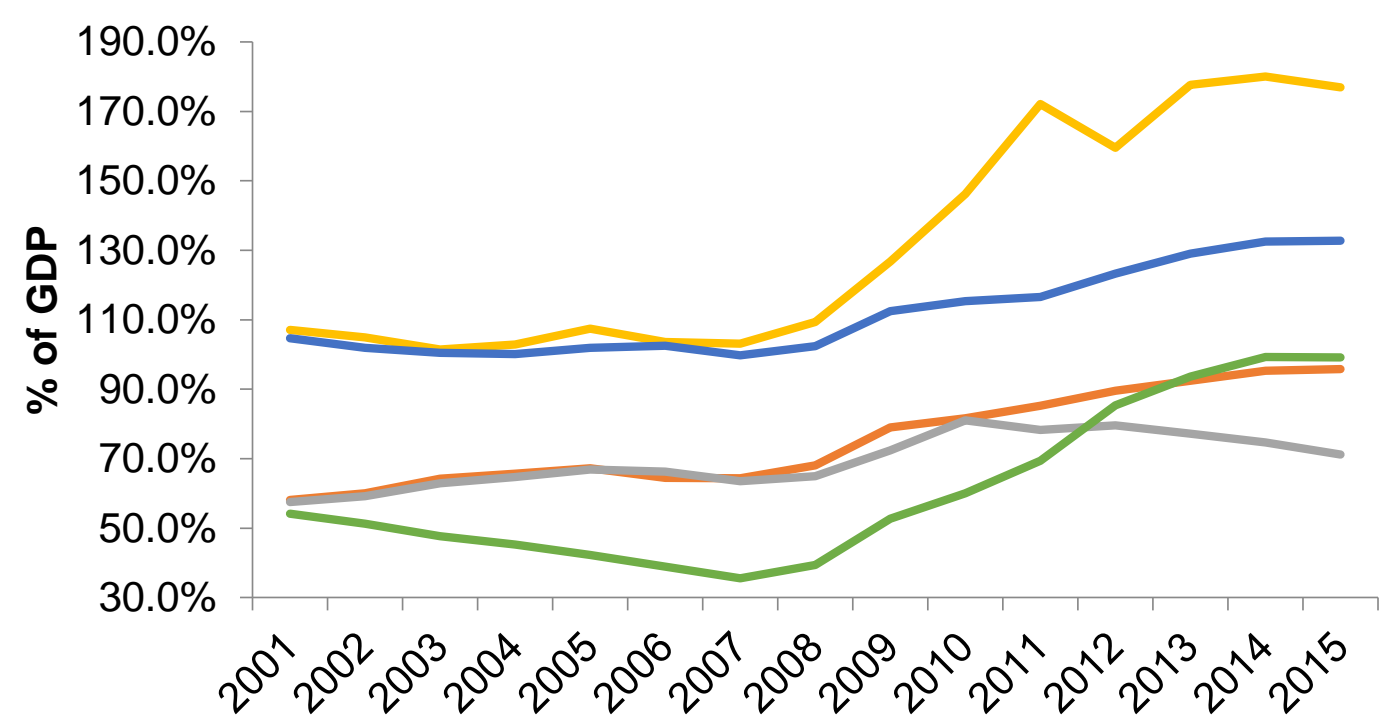

-France - Germany - Greece - Italy - Spain

Source: Constructed from AMECO data.

Figure 4

Nominal Unit Labour Costs

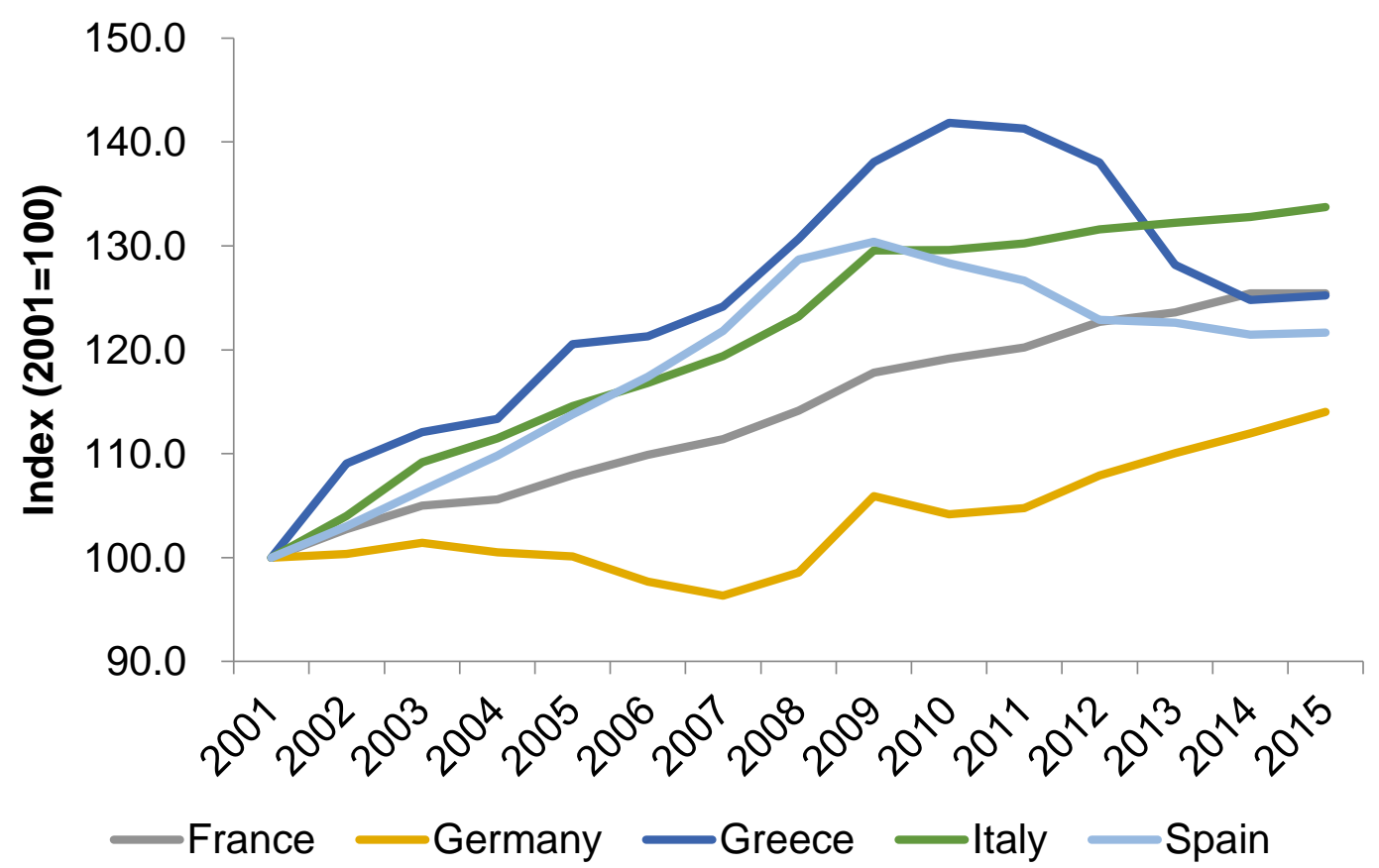

Source: Constructed from AMECO data. 
Figure 5

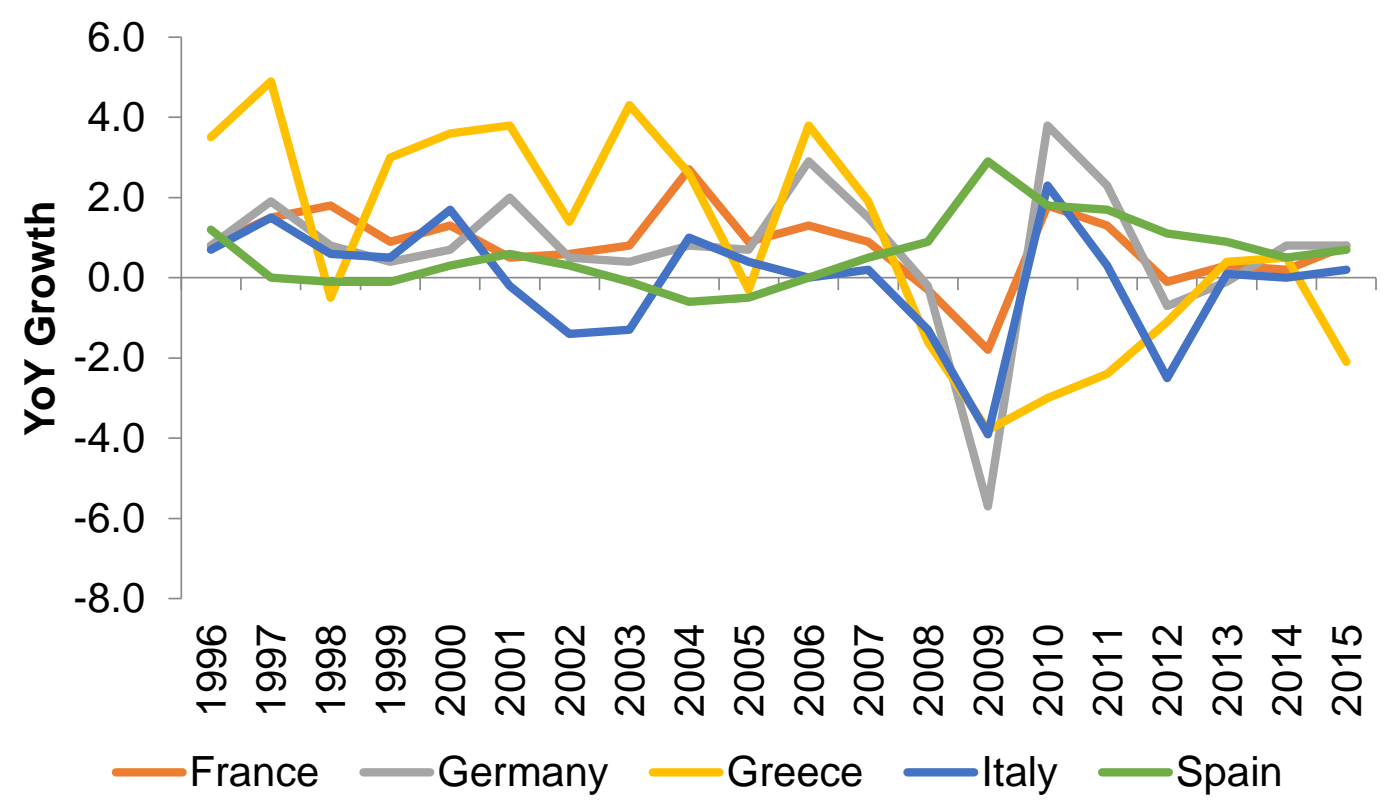

Source: Constructed from AMECO data.

FIG. 6 Real interest rates in the Eurozone

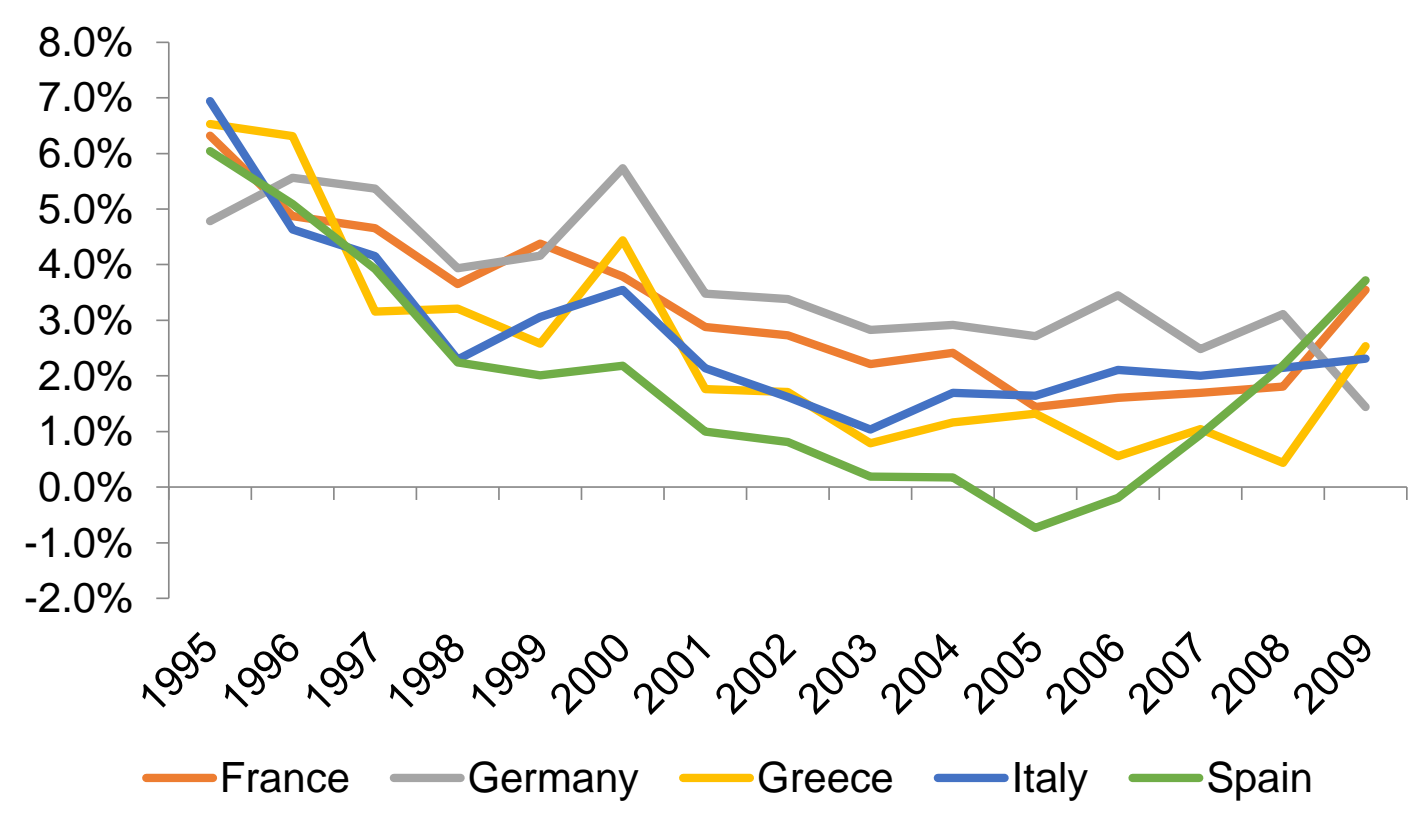

Source: Constructed from AMECO data. 


\section{ENDNOTES}

${ }^{1}$ The literature on sudden reversals in foreign lending is extensive. Calvo et.al. (2006) provide a taxonomy of such crises, mostly in developing countries; see also Calvo (2007). For the EMU, Merler and Pisany-Ferry (2012) have stressed the importance of interrupted cross-border capital flows; see also Baldwin and Giavazzi (2015).

2 See Pisany-Ferry (2011).

${ }^{3}$ Noted with some despair by De Grauwe (2011).

${ }^{4} \mathrm{An}$ early analysis of the Eurozone crisis as a balance of payments, or "sudden stop" crisis, even though the term was not actually deployed, was by Lapavitsas et.al. (2010a), which has subsequently appeared in Lapavitsas et.al. (2012). Note that recognition of the specific form of "sudden stop" crises is not at all the same as accepting a neoclassical analysis of such crises. The dumb fact of capitalist turmoil is (usually) evident to all economists; the analytics deployed to account for it are quite another matter. The present article relies heavily, if implicitly, on the theoretical armoury of Classical and Marxist political economy.

${ }^{5}$ See, for instance, Sinn (2014).

6 See Lapavitsas et.al. (2010a) and Flassbeck and Lapavitsas (2013, 2015); see also Bibow (2012).

7 Note that there are also mainstream expositions of the approach to competitiveness that stresses the problematic nature of German wage policies; see Bofinger (2015) and Wren-Lewis (2015).

${ }^{8}$ See, for instance, Lane (2012).

9 See Nikiforos, Papadimitriou and Zezza (2016).

10 See Flassbeck and Lapavitsas (2015). Perhaps the most sustained examination of the transformation of the EU in view of developments in Germany has been undertaken at the Max Planck Institute in Cologne. See in particular Streeck (2016) whose work on the disintegrating effect of neoliberalism in the EU and the reassertion of the nation state has had the widest impact. See also Scharpf $(2010,2016)$ who has also analysed the rise of neoliberalism in the $\mathrm{EU}$, and more recently examined the rise of German domination and the resulting stratification of the EU. Further incisive political economy analysis of the EU and the euro along similar lines has been undertaken by Hoepner (2014).

11 In political economy terms, the "law of value" does not hold in the world market, as has been known since the days of Ricardo (1817).

12 There is a sizeable literature that engages in precisely such exercises. Thus, Felipe and Kumar (2011), keen to argue that wage reductions would not improve competitiveness, conflated national and enterprise competitiveness. Gabrisch and Staehr (2014), wishing to claim that causality runs from capital flows to unit labour costs - a direction of causation for which there is no coherent argument - ran a series of Granger causality tests the meaning of which is entirely unclear. Storm and Naastepad (2015), on the other hand, in an effort to reject the nominal unit labour cost argument invented an entirely fictitious German productivity miracle. It is interesting to note in this connection that Wyplosz (2013), after doing his best to measure away the divergence of nominal unit labour costs in the Eurozone, concluded that the true cause of the crisis has been booming domestic demand that was either due to credit, or to fiscal deficits.

${ }^{13}$ See Lapavitsas et.al. (2010a).

${ }^{14}$ See Lapavitsas et.al. (2010a).

${ }^{15}$ See Gourinchas, Philippon and Vayanos (2016).

${ }^{16}$ See Lapavitsas et.al. (2010a).

17 See Vavouras (2013).

${ }^{18}$ Aliber (2010) was one of the first to stress the importance of the structural shift in the Greek economy together with the deleterious impact of capital flows and the euro.

19 See Mariolis (2016); see also Lapavitsas et. al., (2010b), which has subsequently appeared in Lapavitsas et.al. (2012). Greek saving is further analysed by Katsimi and Moutos (2010).

20 All figures on Greek debt come from Lapavitsas et. al., (2010b), one of the earliest decompositions of Greek debt following the outbreak of the crisis.

21 On this point see also Gourinchas, Philippon and Vayanos (2016).

22 This view has been prominent among heterodox economists, drawing on post-Keynesian analysis of "finance-led" capitalism, but has also found resonance among mainstream 
economists, for instance, Wyplosz (2013). A variant of it has been strongly put across by Storm and Naastepad (2015).

${ }^{23}$ The explosive growth of financial markets and the expansion of international financial flows do not negate this analytical principle of political economy, but simply give it more complex forms, some of which are concretely discussed in this article in relation to the Eurozone. In contemporary financialised capitalism the penetration of finance in the activities of productive capital add still further complexity, see Lapavitsas (2013).

24 See Artavanis, Morse and Tsoutsoura (2012), who estimate that only in 2009 there were at least $28 \mathrm{bn}$ of unreported income by self-employed professionals, a tremendous sum by Greek standards.

${ }^{25}$ For an acknowledgement of this point from the mainstream see Buti and Carnot (2012) and Obstfeld (2013).

${ }^{26}$ As was pointed out by Buchheit and Gulati (2010) in one of the earliest and most penetrating analyses of Greek public debt.

27 Various aspects of which are discussed in Fine, Lapavitsas and Pincus (2001).

28 See also Pisani-Ferry, Sapir, and Wolff (2013).

29 For the likely implications of devaluation for the Greek economy, see Katsinos and Mariolis (2012), one of the few careful empirical studies of the issue.

${ }_{30}$ For the likely impact on fiscal space of various measures to restructure Greek public debt, see Lapavitsas and Munevar (2014).

${ }^{31}$ See IMF (2016).

32 See IMF (2016, p. 28).

${ }^{33}$ It has been estimated that out of the funds provided to Greece by the first and the second bail-outs, which have together exceeded $215 \mathrm{bn}$, only $9.7 \mathrm{bn}$, or $4.5 \%$, have actually gone to financing primary deficits; the rest have covered the needs of servicing the public debt, i.e., protecting the interests of foreign lenders in the first instance; see Rocholl and Stahmer (2016). ${ }^{34}$ See Blanchard and Leigh (2013).

${ }^{35}$ See Greek Public Debt Management Agency, available at http://www.pdma.gr/index.php/en/ ${ }^{36}$ See Zettelmeyer, Trebesch and Gulati (2013).

37 Wyplosz and Sgherri (2016, p. 41) call it "the most dramatic credit migration from private into official hands in the history of sovereign debt". It was not a "migration" that benefitted the Greek people.

${ }^{38}$ See Flassbeck and Lapavitsas (2013 and 2015).

39 This is one of the most striking aspects of the Fund's internal review; see IMF (2016).

40 See IMF (2016, p.31).

${ }^{41}$ For a penetrating discussion of Gramsci's concept and its usefulness in analysing the Eurozone crisis, see Sotiris (2013).

42 The predatory attitude of the Greek state toward society and its importance in sustaining the power of the "historical bloc" since independence in 1830 has been discussed by Kostis (2015), though certainly not in the same terms, or from the same standpoint, as in this article.

${ }^{43}$ For further discussion of the broader social role of money, see Lapavitsas (2013).

${ }^{44}$ Greece has been very similar to Italy in this respect. The ideological role of the euro in Italy, particularly its association with progress, modernity, efficiency and overcoming various putative national weaknesses has been extensively documented by Giurlando (2016).

45 Exceptions, especially among economists, were remarkably few. Prominent among these were Mariolis (2016) - as well as in several other publications - and Skaperdas (2011).

${ }^{46}$ See Keynes (1929). 